\title{
Ramifications of elevated temperature on the growth and yield performances of rice varieties incorporated with indigenous organic amendments
}

\author{
M. S. Islam ${ }^{1 *}$, H. R. Khan ${ }^{2}$ and M. S. Hossain ${ }^{3}$ \\ ${ }^{1,2}$ Department of Soil, Water and Environment, University of Dhaka, Dhaka-1000, Bangladesh \\ ${ }^{3}$ Department of Environmental Science and Technology, Jashore University of Science and Technology, Jashore-7408, \\ Bangladesh
}

Received: 21 April 2019

Revised: 12 May 2019

Accepted: 01 July 2019

DOI: https://doi.org/10.3329/bjsir.v55i1.46732

\begin{abstract}
A field experiment was conducted at Chandipur of Keraniganj Upazilla in the district of Dhaka, Bangladesh to screen out the studied rice varieties of BR 3, BRRI dhan 28, Local BRRI dhan 29, and BRRI dhan 74 as influenced by the Rice Straw Compost - RSC, Mustard Meal - MM, and Trichocompost - TC (indigenous organic amendments), and elevated soil temperature of $3^{\circ} \mathrm{C}$ in relation to the growth and yield response of rice. The experiment was conducted using split plot design with elevated temperature in main plots and the different rates of organic amendments in subplots. The rates of organic amendments were $0.4,8 \mathrm{t} \mathrm{ha}^{-1}$ for RSC; $0,3,6 \mathrm{tha}^{-1}$ for MM; and 0 , $2.5,5 \mathrm{tha} \mathrm{h}^{-1}$ for TC. The soil temperature was raised by $3^{\circ} \mathrm{C}$ from the daily field temperature of $22-25^{\circ} \mathrm{C}$. Grain and straw yields, 1000 -grain weight, number of filled and fissured grains of rice were significantly $(\mathrm{p} \leq 0.05)$ enhanced with the increased rates of RSC, MM, and TC at elevated temperature of $3^{\circ} \mathrm{C}$. The maximum grain $\left(8.86 \mathrm{t} \mathrm{ha}^{-1}\right)$ and straw $\left(8.40 \mathrm{tha}^{-1}\right)$ yields were recorded in the treatment $\mathrm{RSC}_{4} \mathrm{HW}_{26-28}$ and $\mathrm{RSC}_{8} \mathrm{HW}_{26-28}$, respectively in BRRI dhan 29 over control, which endorsed the lowest grain $\left(3.42 \mathrm{t} \mathrm{ha}^{-1}\right)$ and straw $\left(2.68 \mathrm{tha}^{-1}\right)$ yields. The RSC treatment was ranked first in order of the growth-yield and yield components (1000 - grain weight and No. of filled and fissured grain) of rice followed by MM and TC treatments. The aforesaid treatments were found to have significantly $(\mathrm{p} \leq 0.05)$ positive aftermath with the elevated soil temperature, regardless of rice varieties. Increased rice production by the elevated soil temperature might be due to the $\mathrm{CO}_{2}$ fertilization, which is a very important climatic issue at present day environment.
\end{abstract}

Keywords: Elevated temperature; Rice straw compost; Mustard meal; Trichocompost; Growth-Yield of rice

\section{Introduction}

Agriculture, one of the most promising sectors of agro-based country Bangladesh, has notable contribution of 14.23 percent of the country's Gross Domestic Products (GDP) and employing approximately 47 percent of the total labor force (BBS, 2018). To make a drastic increase in food production and food sufficiency, Bangladesh requires sustainable growth in agricultural sector. Bangladesh ranks 83 positions with a GFSI (Global Food Security Index) score of 43.3 in 2018, which is the lowest among top ten populated countries in the world (EIU, 2018). That's why food security is given top most priority by the government of Bangladesh.Having given supreme priority in domestic food production, greater importance has also been given to ensure access to adequate and safe food for all strata of life to maintain a salubrious life.

Food production is continuously decreasing due to adverse climatic conditions in Bangladesh. In consequence, the requirement of food for the huge population of Bangladesh against this limited cultivable land $(8.51 \mathrm{~m} \mathrm{ha})$ is meager (BBS, 2018). Securing food production has also become a great challenge considering the climate change, land degradation and natural disasters in the highly populated countries in Asia like Bangladesh. In recent years, there have been serious concerns about long-term destructive effects of continuous and indiscriminate use of inorganic fertilizers on deterioration of soil structure, soil health, and environmental

\footnotetext{
*Corresponding author e-mail: islamshifu1998@gmail.com
} 
pollution (Sharma et al., 2004). In contrast, to inorganic fertilizer, the use of bio-control agent, green manures, and other organic amendments can improve soil structure, maintain soil health, increase nutrient uptake, suppress soil borne fungal pathogens and that is why interests have been raising in the usage of organic amendments. Organic amendments are ready source of basic nutrients for crops. These are relatively cheap but a high value nutrient rich bio-fertilizer and can be applied easily in the field.

Rice (Oryza sativa L.), cultivating as food for direct consumption more so than any other crop, is the second largest consumed crop after wheat. Adverse climatic conditions are tentatively forecast to constrain world rice production in 2019 from expanding beyond the 2018 all-time high (FAO, 2019). The world's population continues to grow toward 10 billion by 2050 whereas Bangladesh has an estimated population of 168.02 millionin 2019 which is equivalent to $2.18 \%$ of the total world population (BBS, 2018). To feed this enormous volume it has been forced to extend rice cultivation beyond normal monsoon periods, where temperatures are optimal for growth to warmer summer seasons where high temperature is an important constraint because the predicted changes include the increases in the mean surface temperatures of Earth by $1.5^{\circ} \mathrm{C}-5.8^{\circ} \mathrm{C}$ by 2100 (IPCC, 2018). Against this background, the objective of the present study is to evaluate the effects of soil temperature rise on the growth and yield attributes of rice incorporated with the imposition of rice straw compost, mustard meal, and trichocompost.

\section{Materials and methods}

Description of the study area

A field experiment was carried out at Chandipur, Keraniganj $\left(23^{\circ} 40^{\prime} \mathrm{N}, 90^{\circ} 18^{\prime} \mathrm{E}\right)$, Dhaka, Bangladesh during February to May (Boro season), 2018. The field was formerly cultivated with Grass Pea (Lathyrus sativus) at the early period of Rabi season. The soil belongs to Tejgaon soil series, which had a $\mathrm{pH}$ of $5.3,0.05 \%$ of total $\mathrm{N}, 0.002 \%$ of available $\mathrm{P}$ and $0.01 \%$ of available $\mathrm{K}$. The monthly means for temperature, rainfall, and relative humidity recorded during the field study are shown in Table I.

\section{Planting materials}

Four rice varieties such as BR 3, BRRI dhan 28, Local BRRI dhan 29 and BRRI dhan 74 were used in this study. Forty two-day old seedlings of all these varieties were collected from the seedling division of Bangladesh Rice Research Institute (BRRI), Gazipur. The maturation periods of aforesaid varieties were 170, 140, 160 and 146 days, respectively. Three different indigenous organic amendments viz. Rice Straw Compost (RSC), Mustard Meal (MM) and Tricho-compost (TC) were applied at the rates of $0,4,8 ; 0,3,6$ and $0,2.5,5 \mathrm{t} \mathrm{ha}^{-1}$ (Fig. 1), respectively, at elevated temperature of $26-28^{\circ} \mathrm{C}$ from the daily field temperature of $23-25^{\circ} \mathrm{C}$. (Table II). Rice straw compost and mustard meal were collected from the hybrid division of BRRI. Tricho-compost was collected from the horticulture division of Bangladesh Agriculture Research Institute (BARI), Gazipur.

\section{Experimental design}

The experiment was laid out in a split plot design with three replications, where the main plots were assigned by ambient field temperature and elevated soil temperature as well as the subplots by the different rates of RSC, MM, and TC with the four different rice varieties. Seven subplots $(2 \mathrm{~m} \times 2 \mathrm{~m})$ were assigned in each main plot. A drain $(25 \mathrm{~cm})$ was placed between the main plots to apply hot water. A standard spacing $(10 \mathrm{~cm})$ among the plots and a thick boundary $(15 \mathrm{~cm})$ was also set up around each subplot to prevent any kind of contamination with adjacent subplots. Each subplot (experimental unit)

Table I. Climatic conditions during experimental period

\begin{tabular}{|c|c|c|c|c|}
\hline \multirow[t]{2}{*}{ Month } & \multicolumn{2}{|c|}{ Temperature $\left({ }^{\circ} \mathrm{C}\right)$} & \multirow{2}{*}{$\begin{array}{l}\text { Rainfall } \\
(\mathrm{mm})\end{array}$} & \multirow{2}{*}{$\begin{array}{l}\text { Relative humidity } \\
(\%)\end{array}$} \\
\hline & Minimum & Maximum & & \\
\hline February, 2018 & 26 & 34 & 40 & 62 \\
\hline March, 2018 & 29 & 36 & 75 & 60 \\
\hline April, 2018 & 28 & 36 & 150 & 65 \\
\hline May, 2018 & 27 & 36 & 250 & 70 \\
\hline
\end{tabular}

Source: Meteorological Department of Bangladesh, 2018. 


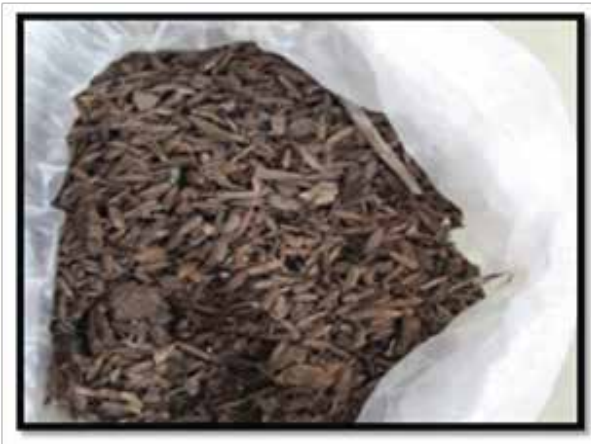

Rice Straw Compost

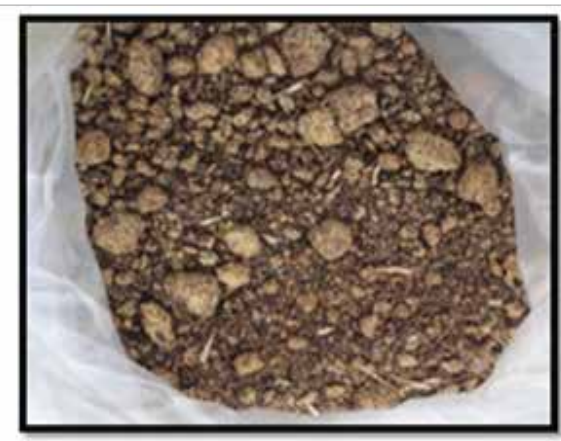

Mustard Meal

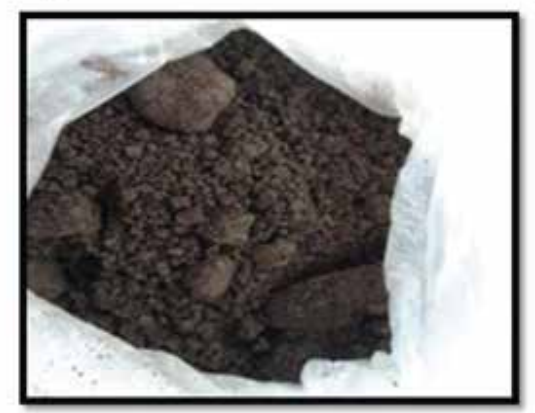

Trichocompost

Fig. 1. Used Organic Amendments in the field experiment

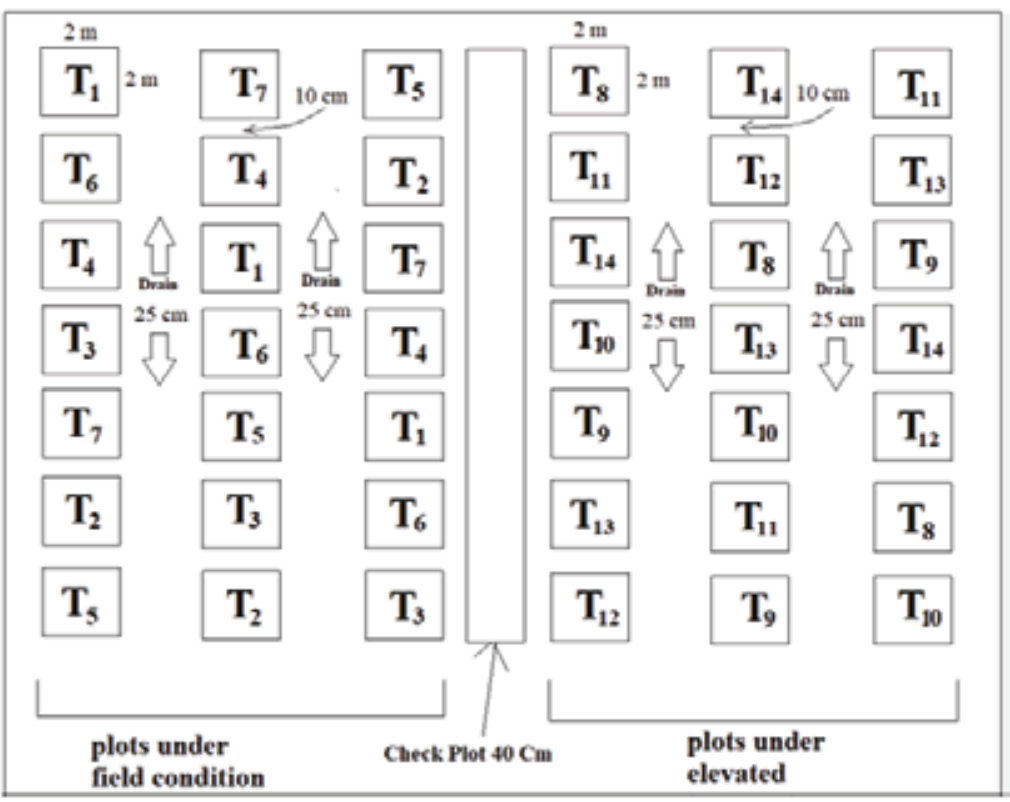

Fig. 2. The layout of the field experiment 
consisted of 8 rows of plants. The seedlings were transplanted at the rate of two seedlings per hill. The hill to hill and row to row distances were $20 \mathrm{~cm}$ and $25 \mathrm{~cm}$, respectively. The first and last rows were used as guard rows, and the others were sampling plants. The layout of the field experiment is exhibited in Fig. 2. The treatment denotations and combination used for the experiment are presented in the Table II.

Table II. Denotation and Combination of the Treatments as applied in the Field Experiment

\begin{tabular}{cc}
\hline Treatment No. & Denotation \\
\hline $\mathrm{T}_{1}$ & Control $\left(\mathrm{RSC}_{0} \mathrm{MM}_{0} \mathrm{TC}_{0} \mathrm{HW}_{23-25}\right)$ \\
$\mathrm{T}_{2}$ & $\mathrm{RSC}_{4}$ \\
$\mathrm{~T}_{3}$ & $\mathrm{RSC}_{8}$ \\
$\mathrm{~T}_{4}$ & $\mathrm{MM}_{6}$ \\
$\mathrm{~T}_{5}$ & $\mathrm{MM}_{12}$ \\
$\mathrm{~T}_{6}$ & $\mathrm{TC}_{2.5}$ \\
$\mathrm{~T}_{7}$ & $\mathrm{TC}_{5}$ \\
$\mathrm{~T}_{8}$ & $\mathrm{RSC}_{0} \mathrm{MM}_{0} \mathrm{TC}_{0} \mathrm{HW}_{26-28}$ \\
$\mathrm{~T}_{9}$ & $\mathrm{RSC}_{4} \mathrm{HW}_{26-28}$ \\
$\mathrm{~T}_{10}$ & $\mathrm{RSC}_{8} \mathrm{HW}_{26-28}$ \\
$\mathrm{~T}_{11}$ & $\mathrm{MM}_{6} \mathrm{HW}_{26-28}$ \\
$\mathrm{~T}_{12}$ & $\mathrm{MM}_{12} \mathrm{HW}_{26-28}$ \\
$\mathrm{~T}_{13}$ & $\mathrm{TC}_{2.5} \mathrm{HW}_{26-28}$ \\
$\mathrm{~T}_{14}$ & $\mathrm{TC}_{5} \mathrm{HW}_{26-28}$ \\
\hline & \\
\hline
\end{tabular}

The $\mathrm{RSC}_{0}, \mathrm{RSC}_{4}, \mathrm{RSC}_{8}$ indicate Rice Straw Compost dose@ rates of 0, 4, $8 \mathrm{tha}^{-1} ; \mathrm{MM}_{0}, \mathrm{MM}_{3}, \mathrm{MM}_{6}$ indicate Mustard Mealdose @ rates of 0,3,6 t ha' ${ }^{-1} \mathrm{TC}_{0}, \mathrm{TC}_{2.5}$, $\mathrm{TC}_{5}$ indicate Tricho-compost dose @ rates of 0,2.5 and $5 \mathrm{t} \mathrm{ha}^{-1} ; \mathrm{HW}_{23-25}$ and $\mathrm{HW}_{26-28}$ indicate soil temperature raising by $3{ }^{\circ} \mathrm{C}$ i.e. $26-28{ }^{\circ} \mathrm{C}$ from the daily field temperature of $23-25{ }^{\circ} \mathrm{C}$.

\section{Elevated temperature treatment}

The soil temperature was raised by $3^{\circ} \mathrm{C}$ i.e. $26-28^{\circ} \mathrm{C}$ from the daily field temperature of $23-25^{\circ} \mathrm{C}$ in the experimental plot by applying hot water on the furrow between the hills of rice plants 30 days after transplantation of seedlings and the heating practice was continued for 7 days separately within 40-90 days of rice growth. Temperature increment was maintained for about 6 to 7 hours in a day. The thermometers were inserted into the ground in each experimental plot to examine and record the temperature rise.

\section{Soil and compost analysis}

After treatment with $1 \mathrm{M} \mathrm{CH}_{3} \mathrm{COONH}_{4}(\mathrm{pH} 5.0)$ and with $30 \% \mathrm{H}_{2} \mathrm{O}_{2}$ to remove free salts and organic matter, respectively. Particle size distribution of the initial soil was determined by the hydrometer method (Piper, 1966). Soil

Table III. Physico-chemical characteristics of initial soil $(1-15 \mathrm{~cm})$ used in the experiment

\begin{tabular}{lc}
\hline \multicolumn{1}{c}{ Properties } & Values \\
\hline Textural class & Clay loam \\
Gravimetric water content $(\%)$ & 2.87 \\
Soil reaction $(\mathrm{pH})$ & 5.55 \\
Electrical conductivity $(\mu \mathrm{S} / \mathrm{cm})$ & 56.9 \\
Organic carbon $(\%)$ & 0.58 \\
Cation exchange capacity $(\mathrm{cmol} / \mathrm{kg})$ & 24.0 \\
Total $\mathrm{N}(\mathrm{mg} / \mathrm{kg})$ & 237.31 \\
Available $\mathrm{NH}_{4}^{+}(\mathrm{mg} / \mathrm{kg})$ & 11.02 \\
Available $\mathrm{NO}{ }_{3}^{-}(\mathrm{mg} / \mathrm{kg})$ & 51.98 \\
Available $\mathrm{P}(\mathrm{mg} / \mathrm{kg})$ & 82.10 \\
Available $\mathrm{S}(\mathrm{mg} / \mathrm{kg})$ & 22.28 \\
Available $\mathrm{Na}(\mathrm{cmol} / \mathrm{kg})$ & 1.14 \\
Available $\mathrm{K}(\mathrm{cmol} / \mathrm{kg})$ & 8.40 \\
Available $\mathrm{Ca}(\mathrm{cmol} / \mathrm{kg})$ & 9.28 \\
Available $\mathrm{Mg}(\mathrm{cmol} / \mathrm{kg})$ & 1.32 \\
\hline
\end{tabular}


$\mathrm{pH}$ was measured in the field by the soil-water ratio of 1:2.5 (Jackson, 1973) using a Corning pH meter model-7. The electrical conductivity of soil solution was determined at the ratio of 1:5 (Richards, 1954). Organic matter content was determined by wet combustion with $\mathrm{K}_{2} \mathrm{Cr}_{2} \mathrm{O}_{7}$ (Nelson and Sommers, 1982). The CEC was determined by Micro-Kjeldahl method (Jackson, 1973). Available N was determined by $1.3 \mathrm{M} \mathrm{KCl}$ extraction, micro-steam distillation method using Devarda's alloy (Jackson, 1973), available $\mathrm{P}$ by Bray No. 1 extraction method (Bray and Kurtz 1945), available $\mathrm{S}$ by $\mathrm{BaCl}_{2}$ turbidity (Page et al. 1989). Available cations viz. $\mathrm{Na}^{+}, \mathrm{K}^{+}, \mathrm{Ca}^{2+}$ and $\mathrm{Mg}^{2+}$ extracted with $1 \mathrm{M} \mathrm{CH}_{3} \mathrm{COONH}_{4}(\mathrm{pH}$ 7.0) and the extracts were analyzed for $\mathrm{Na}^{+}$and $\mathrm{K}^{+}$by flame photometer and for

\section{Results and discussion}

\section{Height of rice plants}

The average height of rice plants measured at the maturity stage (110 DAT) revealed that the height of the plants increased with the increased levels of organic amendments alone and in combination with the elevated temperature of $3^{\circ} \mathrm{C}$. The height of rice varieties was showed positive relationship with the elevated temperature of $3^{\circ} \mathrm{C}$. The treatment, $\mathrm{T}_{10}\left(\mathrm{RSC}_{8} \mathrm{HW}_{26-28}\right)$ had the highest positive impact on the height $(95 \mathrm{~cm})$ of rice during maturity stage and the lowest plant height $(72 \mathrm{~cm})$ was obtained for the control plot where no treatment was applied (Fig. 3).

Table IV. Composition and nutrient contents of organic amendments used in the experiment

\begin{tabular}{|c|c|c|c|c|c|}
\hline \multirow[t]{2}{*}{ Organic Amendments } & \multirow[t]{2}{*}{ Composition } & \multicolumn{4}{|c|}{ Nutrient contents } \\
\hline & & $\mathrm{N}(\%)$ & $\mathrm{P}(\%)$ & K (\%) & $\mathrm{S}(\%)$ \\
\hline Rice straw compost & Decomposed straw of rice & 1.05 & 0.10 & 1.50 & - \\
\hline Mustard meal & By-product of mustard oil seed crop & 5.20 & 0.79 & 1.00 & - \\
\hline Tricho-compost & $\begin{array}{l}\text { Spore suspension of a Trichoderma harzianum }+ \\
\text { processed raw material (cow dung }+ \text { poultry } \\
\text { refuse }+ \text { water hyacinth }+ \text { vegetable waste }+ \text { saw } \\
\text { dust }+ \text { maize bran }+ \text { molasses })\end{array}$ & 2.42 & 1.26 & 1.42 & 0.41 \\
\hline
\end{tabular}

$\mathrm{Ca}^{2+}$ and $\mathrm{Mg}^{2+}$ by atomic absorption spectrophotometer. The properties of the soil are presented in Table III. Total nitrogen of the used organic amendments was determined by Kjeldahl method (Stevenson, 1982). Total phosphorus of the amendments was measured colorimetrically using spectrophotometer, where the amendments were digested in conc. $\mathrm{H}_{2} \mathrm{SO}_{4}+\mathrm{H}_{2} \mathrm{O}_{2}$. The composition of the used organic amendments is shown in Table IV.

Plant sampling for growth and growth-yield parameter measurements

In each subplot, two row strips $(25 \mathrm{~cm})$ were randomly selected and tagged in two different rows within the sampling area. Selected tillers from those row strips were collected at $1.0 \mathrm{~cm}$ above the ground level during the crops of maturity at 110 days after transplantation for the measurements of the height of rice plants, straw yield, grain yield, number of filled and fissured grains per panicle and 1000-grain weight.
Almost similar and significant $(\mathrm{p} \leq 0.05)$ positive effects on plant heights were studied for all rice varieties. The plant height was recorded as the highest in BRRI dhan 29 followed by the order of BRRI dhan $74>$ BRRI dhan 28 $>$ BR 3. The observed results are in agreement with the findings of Akter et al., 2017. They revealed that increase in vegetative growth might be due to better flow of various macro and micro nutrients along with plant growth substances into the plant system in the plots applied with organic amendment in the form of tricho-compost. Quite similar study was conducted by the scientists and they claimed that rice plants grown on soils treated with rice straw were significantly taller than those grown on soils without treatment. Incorporation of rice straw into the soil combined with application of cattle manure gave the maximum plant height. In a study, Oh-e et al. 2007 reported that the increase in plant height was steeper under high temperature within the range of $30-35^{\circ} \mathrm{C}$ than under ambient temperature condition, which agrees with the finding of this study. 


\section{Straw yield}

Straw dry matter production of rice varieties was found to be increased significantly $(\mathrm{p} \leq 0.05)$ by the application of $\mathrm{RSC}, \mathrm{MM}$ and TC incorporated with elevated temperature of $26-28^{\circ} \mathrm{C}$, while their increased doses were found to be more effective in the increment of the straw yield (Table $\mathrm{V})$. The highest straw yield $\left(8.00 \mathrm{tha}^{-1}\right)$ was recorded at the maturity stage of rice in the treatment $\mathrm{T}_{3}\left(\mathrm{RSC}_{8}\right)$ over control, where the lowest straw yield $\left(2.68 \mathrm{t} \mathrm{ha}^{-1}\right)$ was

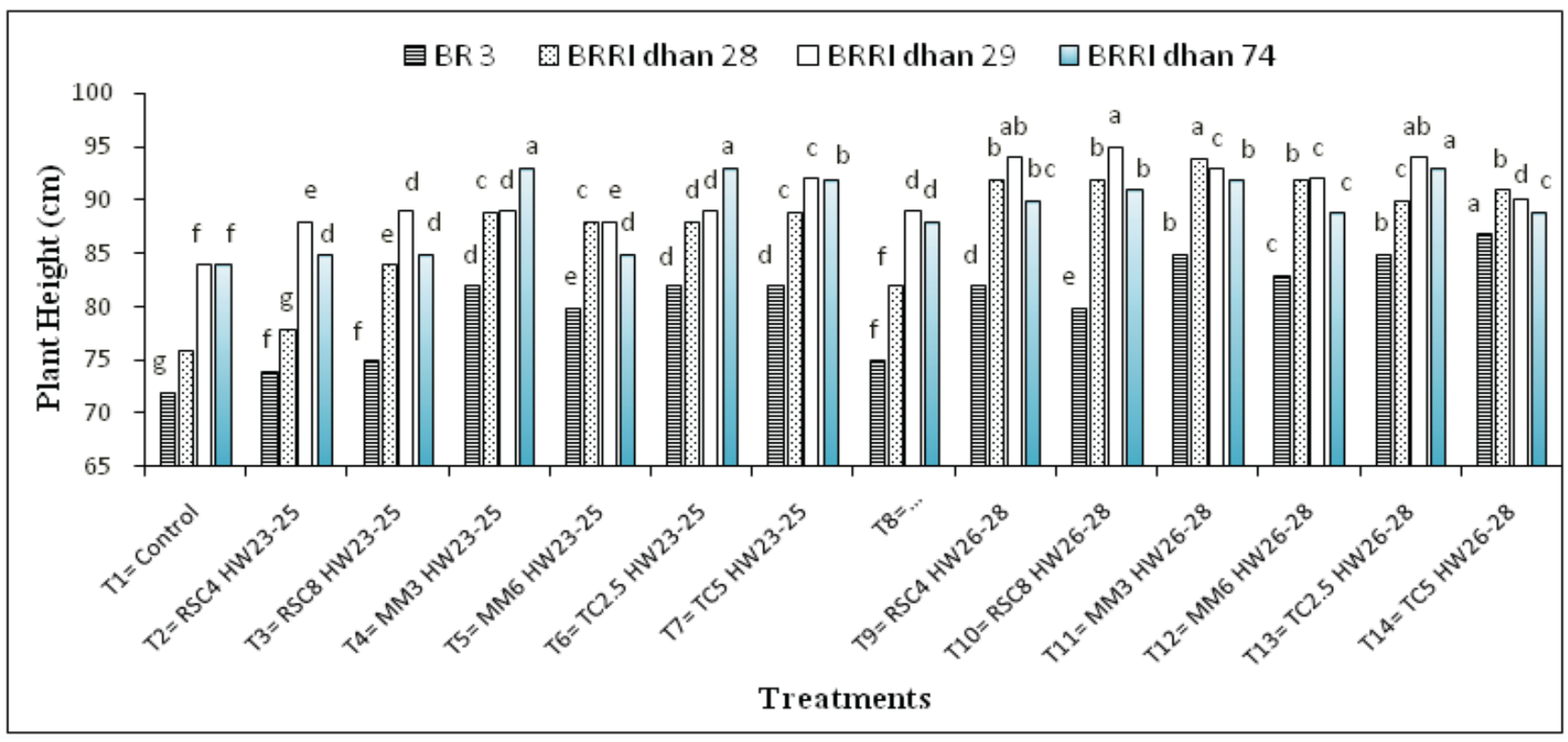

Fig. 3. Effects of rice straw compost, mustard meal and tricho-compost on the height of rice plants as influenced by elevated temperature

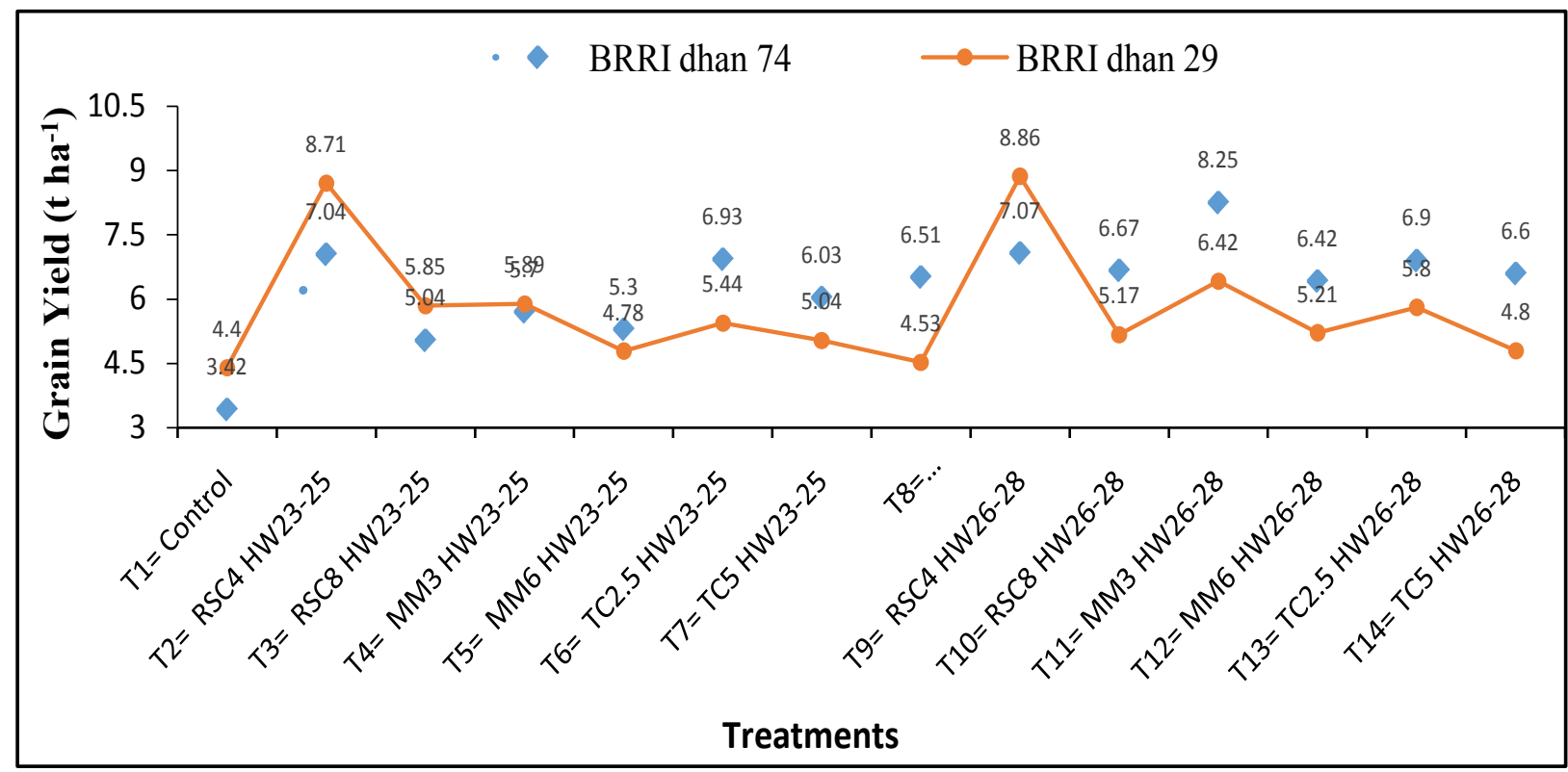

Fig. 4. Comparison of grain yield of rice (t ha-1) between BRRI dhan 74 and Local BRRI dhan 29 as influenced by rice straw compost, mustard meal, tricho-compost and elevated soil temperature 


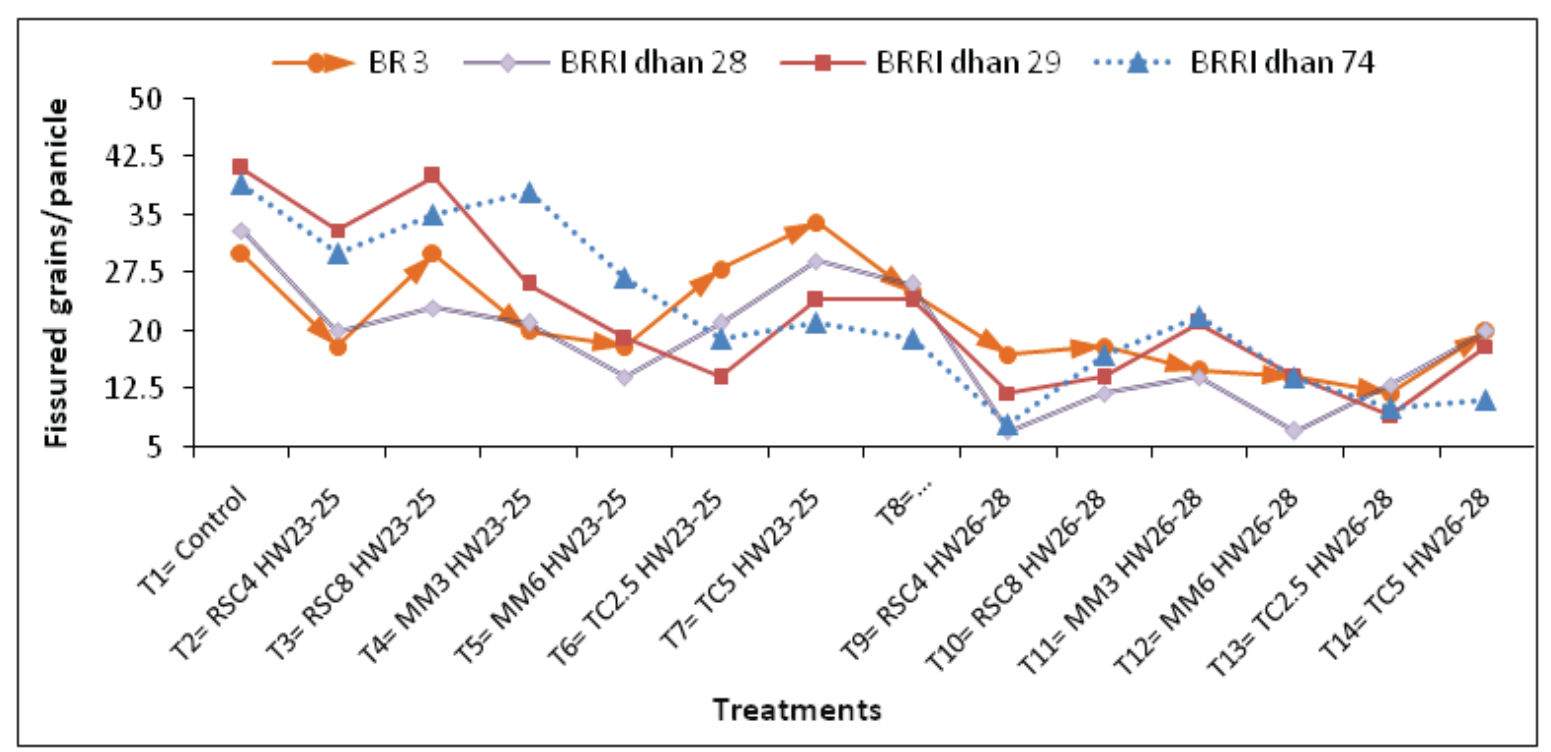

Fig. 5. Influences of rice straw compost, mustard meal and tricho-compost on the number of fissured grain per panicle as affected by elevated temperature

Table V. Influences of indigenous organic amendments on the straw yield ( $\left.\mathrm{t} \mathrm{ha-}{ }^{1}\right)$ of four rice varieties incorporated with elevated temperature

\begin{tabular}{|c|c|c|c|c|}
\hline \multirow[t]{2}{*}{ Treatment } & \multicolumn{4}{|c|}{ Straw Yield (t ha- $\left.{ }^{1}\right)$} \\
\hline & BR 3 & BRRI dhan 28 & BRRI dhan 29 & BRRI dhan 74 \\
\hline $\mathrm{T}_{1}$ & $3.04 \mathrm{k}$ & $3.09 \mathrm{e}$ & $2.90 \mathrm{~m}$ & 2.681 \\
\hline $\mathrm{T}_{2}$ & $4.18 \mathrm{e}$ & $4.38 \mathrm{i}$ & $6.28 \mathrm{~b}$ & $2.99 \mathrm{j}$ \\
\hline $\mathrm{T}_{3}$ & $5.84 \mathrm{~b}$ & $4.88 \mathrm{f}$ & $8.00 \mathrm{a}$ & $3.86 \mathrm{i}$ \\
\hline $\mathrm{T}_{4}$ & $3.94 \mathrm{~g}$ & $5.68 \mathrm{~b}$ & $4.58 \mathrm{f}$ & $4.92 \mathrm{c}$ \\
\hline $\mathrm{T}_{5}$ & $4.12 \mathrm{f}$ & $5.36 \mathrm{~d}$ & $4.78 \mathrm{e}$ & $5.20 \mathrm{~b}$ \\
\hline $\mathrm{T}_{6}$ & $3.14 \mathrm{j}$ & $3.44 \mathrm{j}$ & $3.80 \mathrm{j}$ & $3.90 \mathrm{hi}$ \\
\hline $\mathrm{T}_{7}$ & $3.90 \mathrm{~g}$ & $4.48 \mathrm{~h}$ & $3.90 \mathrm{i}$ & $4.00 \mathrm{~g}$ \\
\hline $\mathrm{T}_{8}$ & $3.10 \mathrm{j}$ & $2.84 \mathrm{~m}$ & 3.061 & $2.91 \mathrm{k}$ \\
\hline $\mathrm{T}_{9}$ & $3.36 \mathrm{I}$ & $4.76 \mathrm{~g}$ & $4.38 \mathrm{~g}$ & $3.94 \mathrm{~h}$ \\
\hline $\mathrm{T}_{10}$ & $5.54 \mathrm{~d}$ & $6.12 \mathrm{a}$ & $5.62 \mathrm{~d}$ & $4.20 \mathrm{f}$ \\
\hline $\mathrm{T}_{11}$ & $5.72 \mathrm{c}$ & $3.19 \mathrm{k}$ & $4.04 \mathrm{~h}$ & $4.34 \mathrm{e}$ \\
\hline $\mathrm{T}_{12}$ & $3.12 \mathrm{j}$ & $5.44 \mathrm{c}$ & $3.70 \mathrm{k}$ & $4.80 \mathrm{~d}$ \\
\hline $\mathrm{T}_{13}$ & $3.64 \mathrm{~h}$ & $5.16 \mathrm{e}$ & $5.82 \mathrm{c}$ & $4.96 \mathrm{c}$ \\
\hline $\mathrm{T}_{14}$ & $6.52 \mathrm{a}$ & $4.40 \mathrm{i}$ & $4.82 \mathrm{e}$ & $5.84 \mathrm{a}$ \\
\hline
\end{tabular}

In a column, means that do not share same letter are significantly different at 5\% level by Tukey's Range Test. 
Table VI. Comparison of Grain Yield $\left(\mathrm{t} \mathrm{ha}^{-1}\right)$ of rice at elevated temperature as influenced by the application of rice straw compost, mustard meal and tricho-compost

\begin{tabular}{|c|c|c|c|c|}
\hline \multirow[t]{2}{*}{ Treatment } & \multicolumn{4}{|c|}{ Grain Yield ( $\left.\mathrm{t} \mathrm{ha-}{ }^{1}\right)$} \\
\hline & BR 3 & BRRI dhan 28 & BRRI dhan 29 & BRRI dhan 74 \\
\hline $\mathrm{T}_{1}$ & $4.81 \mathrm{~h}$ & $4.56 \mathrm{~m}$ & $4.40 \mathrm{k}$ & 3.421 \\
\hline $\mathrm{T}_{2}$ & $6.69 \mathrm{c}$ & $6.66 \mathrm{~g}$ & $8.71 \mathrm{~b}$ & $7.04 \mathrm{~b}$ \\
\hline $\mathrm{T}_{3}$ & $4.35 \mathrm{j}$ & $5.80 \mathrm{i}$ & $5.85 \mathrm{de}$ & $5.04 \mathrm{k}$ \\
\hline $\mathrm{T}_{4}$ & $6.49 \mathrm{~d}$ & $7.77 \mathrm{~b}$ & $5.89 \mathrm{~d}$ & $5.70 \mathrm{i}$ \\
\hline $\mathrm{T}_{5}$ & $6.09 \mathrm{f}$ & $5.69 \mathrm{j}$ & $4.78 \mathrm{i}$ & $5.30 \mathrm{j}$ \\
\hline $\mathrm{T}_{6}$ & $6.06 \mathrm{f}$ & $6.77 \mathrm{f}$ & $5.44 \mathrm{f}$ & $6.93 \mathrm{c}$ \\
\hline $\mathrm{T}_{7}$ & $5.64 \mathrm{~g}$ & $5.23 \mathrm{k}$ & $5.04 \mathrm{~h}$ & $6.03 \mathrm{~h}$ \\
\hline $\mathrm{T}_{8}$ & 4.081 & $6.44 \mathrm{~h}$ & $4.53 \mathrm{j}$ & $6.51 \mathrm{f}$ \\
\hline $\mathrm{T}_{9}$ & $6.84 \mathrm{~b}$ & $6.70 \mathrm{~g}$ & $8.86 \mathrm{a}$ & $7.07 \mathrm{~b}$ \\
\hline $\mathrm{T}_{10}$ & $4.71 \mathrm{i}$ & $7.26 \mathrm{~d}$ & $5.17 \mathrm{~g}$ & $6.67 \mathrm{~d}$ \\
\hline $\mathrm{T}_{11}$ & $6.19 \mathrm{e}$ & $7.86 \mathrm{a}$ & $6.42 \mathrm{c}$ & $8.25 \mathrm{a}$ \\
\hline $\mathrm{T}_{12}$ & $4.80 \mathrm{~h}$ & 5.091 & $5.21 \mathrm{~g}$ & $6.42 \mathrm{~g}$ \\
\hline $\mathrm{T}_{13}$ & $6.97 \mathrm{a}$ & $7.59 \mathrm{c}$ & $5.80 \mathrm{e}$ & $6.90 \mathrm{c}$ \\
\hline $\mathrm{T}_{14}$ & $4.17 \mathrm{k}$ & $6.91 \mathrm{i}$ & $4.80 \mathrm{i}$ & $6.60 \mathrm{e}$ \\
\hline
\end{tabular}

In a column, means that do not share same letter are significantly different at 5\% level by Tukey's Range Test.

attained. These effects of amendments were increased most in BRRI dhan 29 followed by BR 3, BRRI dhan 28 and BRRI dhan 74. These findings are in close conformity with the results reported by Goyal et al. 1992; Yoshida, 1973 and Islam et al., 2020. They revealed that the straw yield of rice increased with inorganic fertilizers alone or along with organic residues in the form of rice straw compost (RSC) significantly due to better flow of various macro and micro nutrients along with plant growth substances into the plant system in the experimental plots. A satisfactory result was attained due to temperature rise. This might be due to increased synchronism and mobilization of assimilates and nutrients among tillers at high temperature. The present results are quite similar with the findings of Yoshida, 1973.

\section{Grain yield}

A synergistic interaction was found between the applied rates of organic amendments and the grain yield of rice. The grain yield increased comprehensively with moderate rates of RSC, MM and TC alone or in combination with raised soil temperature of $26-28^{\circ} \mathrm{C}$ from the daily field temperature of $23-25^{\circ} \mathrm{C}$. The average grain yield was found to be maximum $\left(8.86 \mathrm{t} \mathrm{ha} \mathrm{ha}^{-1}\right)$ in treatment $\mathrm{T}_{9}\left(\mathrm{RSC}_{4} \mathrm{HW}_{26-28}\right)$ and the minimum (3.42 $\left.\mathrm{t} \mathrm{ha}^{-1}\right)$ in control, where field temperature was practicedwith no amendments (Table VI). Yield of rice was attained maximum at the moderate rates of RSC ( $\left.4 \mathrm{tha}^{-1}\right)$ followed by MM ( $\left.3 \mathrm{t} \mathrm{ha}^{-1}\right)$ and TC $\left(2.5 \mathrm{t} \mathrm{ha}^{-1}\right)$ than the highest rates viz. 8, 6 and $5 \mathrm{t}$ $\mathrm{ha}^{-1}$, respectively. Grain yield was increased most in BRRI dhan 29 followed by BRRI dhan 74, BRRI dhan 28 and BR 3 (Table VI). The growth and yield of BRRI dhan 74 was 
Table VII. Influences of elevated temperature and organic amendments on the number of filled grains per panicle of four rice varieties grown under field condition

\begin{tabular}{|c|c|c|c|c|}
\hline \multirow[t]{2}{*}{ Treatment } & \multicolumn{4}{|c|}{ Filled grains (No./panicle) } \\
\hline & BR 3 & BRRI dhan 28 & BRRI dhan 29 & BRRI dhan 74 \\
\hline $\mathrm{T}_{1}$ & $57 \mathrm{~h}$ & $72 \mathrm{i}$ & $71 \mathrm{de}$ & $68 \mathrm{j}$ \\
\hline $\mathrm{T}_{2}$ & $94 \mathrm{a}$ & $127 \mathrm{c}$ & $100 \mathrm{~b}$ & $110 \mathrm{bc}$ \\
\hline $\mathrm{T}_{3}$ & $82 \mathrm{cde}$ & $134 \mathrm{~b}$ & $154 \mathrm{a}$ & 100 ef \\
\hline $\mathrm{T}_{4}$ & $85 \mathrm{bcd}$ & $139 \mathrm{~b}$ & $81 \mathrm{c}$ & 148 a \\
\hline $\mathrm{T}_{5}$ & $73 \mathrm{f}$ & $76 \mathrm{i}$ & $56 \mathrm{f}$ & $66 \mathrm{j}$ \\
\hline $\mathrm{T}_{6}$ & $40 \mathrm{j}$ & $111 \mathrm{de}$ & $73 \mathrm{~d}$ & $104 \mathrm{de}$ \\
\hline $\mathrm{T}_{7}$ & $46 \mathrm{i}$ & $103 \mathrm{fg}$ & $45 \mathrm{~g}$ & $88 \mathrm{~h}$ \\
\hline $\mathrm{T}_{8}$ & $74 \mathrm{f}$ & $92 \mathrm{~h}$ & $85 \mathrm{c}$ & $95 \mathrm{fg}$ \\
\hline $\mathrm{T}_{9}$ & $80 \mathrm{de}$ & $98 \mathrm{~g}$ & $104 \mathrm{~b}$ & $102 \mathrm{de}$ \\
\hline $\mathrm{T}_{10}$ & $87 \mathrm{bc}$ & $115 \mathrm{~d}$ & $67 \mathrm{e}$ & $94 \mathrm{~g}$ \\
\hline $\mathrm{T}_{11}$ & $88 \mathrm{~b}$ & $139 \mathrm{~b}$ & $81 \mathrm{c}$ & $114 \mathrm{~b}$ \\
\hline $\mathrm{T}_{12}$ & 77 ef & $105 \mathrm{f}$ & $60 \mathrm{f}$ & $107 \mathrm{~cd}$ \\
\hline $\mathrm{T}_{13}$ & $87 \mathrm{bc}$ & $165 \mathrm{a}$ & $80 \mathrm{c}$ & $76 \mathrm{i}$ \\
\hline $\mathrm{T}_{14}$ & $65 \mathrm{~g}$ & 106 ef & $101 \mathrm{~b}$ & $92 \mathrm{gh}$ \\
\hline
\end{tabular}

In a column, means that do not share same letter are significantly different at 5\% level by Tukey's Range Test.

almost in close proximity to Local BRRI dhan 29 (Fig. 4). Similar observations have been made by Goyal et al. 1992 and they reported that the grain yield increased with the application of rice straw compost due to an overall improvement in the chemical and biological properties of soil. At elevated temperature the grain yield was found to be highest. This might be due to improved rate of photosynthesis and more translocation of assimilates towards grain. A previous researcher Idso (1991) in a challenging paper reported that about $5-10 \%$ of the actual rate of increase of agricultural productivity worldwide can be ascribed to the fertilizing effect of rising atmospheric $\mathrm{CO}_{2}$ level which is quite similar to this study. The observed results are also in agreement with the findings of Krishnan et al. 2011.

\section{Number of filled grains per panicle}

Number of filled grains was found to be positively significant $(p \leq 0.05)$ with the individual application of different rates of RSC, MM and TC, while the combination of these amendments incorporated with the elevated temperature of $26-28^{\circ} \mathrm{C}$ was more pronounced (Table VII). The maximum number of filled grains (165/panicle) was attained from the treatment $\mathrm{T}_{13}\left(\mathrm{TC}_{2.5} \mathrm{HW}_{26-28}\right)$ and the minimum number of filled grains (57/panicle) was recorded in control where field temperature of $23-25^{\circ} \mathrm{C}$ was practiced with no amendments (Table VII). The number of filled grains was increased maximum in BRRI dhan 28 followed by BRRI dhan 29, BRRI dhan 74 and BR 3 . The number of filled grains was increased at elevated temperature along with increased rates of organic amendments. But according to the previous study, the 
number of filled grains is inversely correlated with temperature which is contradicted to this study. This might be due to boost up of translocation of assimilates to the grains for the combined effect of organic amendments and elevated temperature. However, the results from the experiment of Tian et al. 2009 and Xie et al. 2009 partially agree with the present finding.

\section{Number of fissured grains per panicle}

The interacting effect of organic amendment application rates and elevated temperature on the number of fissured grains per panicle was significant $(p \leq 0.05)$. The number of fissured grains was reduced with increased rates of organic amendments along with the temperature rise of $26-28^{\circ} \mathrm{C}$. The lowest number of fissured grains (3/panicle) was recorded at treatment $\mathrm{T}_{9}\left(\mathrm{RSC}_{4} \mathrm{HW}_{26-28}\right)$ and $\mathrm{T}_{13}$ $\left(\mathrm{TC}_{2.5} \mathrm{HW}_{26-28}\right)$, whereas the highest fissured grains (41/panicle) was recorded in control condition (Fig. 5). The number of fissured grains was decreased most in BRRI dhan 28 followed by BRRI dhan 74, BRRI dhan 29 and BR 3. The elevated temperature along with application of organic amendments might play a pivotal role to reduce the number of fissured grain by avoiding incomplete development of pollen tube, insufficient assimilates production and its distribution to grains.

Table VIII. Effects of elevated temperature and indigenous organic amendments on 1000 grain weight of four rice varieties grown under field condition

\begin{tabular}{ccccc}
\hline Treatment & \multicolumn{4}{c}{1000 grain weight $(\mathrm{g})$} \\
\cline { 2 - 4 } $\mathrm{T}_{1}$ & $20.5 \mathrm{j}$ & BRRI dhan 28 & BRRI dhan 29 & BRRI dhan 74 \\
$\mathrm{~T}_{2}$ & $33.3 \mathrm{~b}$ & $21.7 \mathrm{i}$ & $20.4 \mathrm{j}$ & $20.0 \mathrm{k}$ \\
$\mathrm{T}_{3}$ & $28.8 \mathrm{e}$ & $31.8 \mathrm{a}$ & $32.1 \mathrm{~b}$ & $32.7 \mathrm{~b}$ \\
$\mathrm{~T}_{4}$ & $22.4 \mathrm{i}$ & $27.0 \mathrm{e}$ & $21.4 \mathrm{i}$ & $38.0 \mathrm{a}$ \\
$\mathrm{T}_{5}$ & $29.5 \mathrm{~d}$ & $28.0 \mathrm{~d}$ & $22.6 \mathrm{i}$ \\
$\mathrm{T}_{6}$ & $31.0 \mathrm{c}$ & $28.7 \mathrm{c}$ & $24.9 \mathrm{~g}$ & $28.9 \mathrm{e}$ \\
$\mathrm{T}_{7}$ & $26.8 \mathrm{~g}$ & $27.4 \mathrm{e}$ & $28.6 \mathrm{~d}$ & $23.3 \mathrm{~h}$ \\
$\mathrm{~T}_{8}$ & $28.6 \mathrm{e}$ & $25.5 \mathrm{f}$ & $28.8 \mathrm{~cd}$ & $21.9 \mathrm{j}$ \\
$\mathrm{T}_{9}$ & $34.0 \mathrm{a}$ & $25.6 \mathrm{f}$ & $34.3 \mathrm{a}$ & $22.6 \mathrm{i}$ \\
$\mathrm{T}_{10}$ & $29.9 \mathrm{~d}$ & $29.0 \mathrm{bc}$ & $25.5 \mathrm{f}$ & $38.3 \mathrm{a}$ \\
$\mathrm{T}_{11}$ & $29.8 \mathrm{~d}$ & $29.4 \mathrm{~b}$ & $23.1 \mathrm{~h}$ & $26.4 \mathrm{~g}$ \\
$\mathrm{~T}_{12}$ & $24.6 \mathrm{~h}$ & $28.9 \mathrm{bc}$ & $26.9 \mathrm{e}$ & $29.5 \mathrm{~d}$ \\
$\mathrm{~T}_{13}$ & $29.8 \mathrm{~d}$ & $23.8 \mathrm{~h}$ & $29.2 \mathrm{c}$ & $22.7 \mathrm{i}$ \\
$\mathrm{T}_{14}$ & $27.4 \mathrm{f}$ & $27.4 \mathrm{e}$ & $26.7 \mathrm{e}$ & $30.1 \mathrm{c}$ \\
\hline
\end{tabular}

In a column, means that do not share same letter are significantly different at $5 \%$ level by Tukey's Range Test. 


\section{Grain weight}

The ANOVA and Tukey's Range Test showed that 1000 grain weight of rice significantly $(p \leq 0.05)$ enhanced with the increased rates of RSC, MM and TC alone or in combination with the elevated soil temperature of $26-28^{\circ} \mathrm{C}$. The treatment, $\mathrm{T}_{9}\left(\mathrm{RSC}_{4} \mathrm{HW}_{26-28}\right)$ contributed the highest grain weight $(38.3 \mathrm{~g})$ of rice over control, which endorsed the lowest grain weight (20.0 g) shown in Table VIII. The 1000 grain weight was obtained maximum in BRRI dhan 74 followed by BRRI dhan 29, BR 3 and BRRI dhan 28. These results are contrasted with the findings of previous workers Murata, 1976. He reported that 1000 grain weight of rice varied from about $24 \mathrm{~g}$ at a mean temperature of $22^{\circ} \mathrm{C}$ in the three week periods after heading to $21 \mathrm{~g}$ at mean temperature of $28^{\circ} \mathrm{C}$. However, in the present study, we have applied organic amendments which might cause the increment of 1000-grain weight by providing adequate supply of nutrients.

\section{Conclusion}

The study was concluded that the application of organic amendments incorporated with elevated temperature of $26-28^{\circ} \mathrm{C}$ was exerted the best growth and yield performances by rice varieties of BRRI dhan 29 followed by BRRI dhan 74, BRRI dhan 28 and BR 3. The growth and yield of BRRI dhan 74 was almost in close proximity to Local BRRI dhan 29. So, it was recommended to farmers to cultivate BRRI dhan 74 for attaining the maximum yield as like as BRRI dhan 29. In addition, the application of rice straw compost at the rate of $4 \mathrm{t} \mathrm{ha}^{-1}$ along with soil temperature riseof $26-28^{\circ} \mathrm{C}$ showed significantly better result in plant height, straw yield, grain yield, number of filled and fissured grains and weight of 1000-grain followed by mustard meal at the rate of $3 \mathrm{tha}^{-1}$ and tricho-compost at $2.5 \mathrm{t} \mathrm{ha}^{-1}$. Hence, the application of organic amendments in this combination is considered as the best to get the highest yield of rice. As a whole, this study might be a gleam for livelihood against all negative aspects of global warming and climate change.

\section{Acknowledgement}

The study was carried out under a project of the Climate Change Trust Fund (CCTF) entitled 'Assessment of Impacts of Climate Change on Soil Health and Food Security, and Adaptation of Climate-smart Agriculture in Most Adversely Affected Areas of Bangladesh'funded by the MoEFCC (2017-18, DU 410), Government of the Peoples' Republic of Bangladesh. We are also grateful to Bangladesh Rice Research Institute (BRRI) and
Bangladesh Agricultural Research Institute (BARI) for the supply of planting materials.

\section{References}

Akter N, Ara KA, Akand MH and Alam MK (2017), Vermicompost and trrichocompost in combination with inorganic fertilizer: increased growth, flowering and yield of gladiolus cultivar (GL-031), Advances in Res. 12(3): 1-11. DOI: 10.9734/AIR/2017/37034

BBS (2018), Statistical yearbook of Bangladesh, Ministry of Planning, Government of the People's Republic of Bangladesh, pp 33-36.

BMD (2018), Forecast of the period from 10/2/2018 to 20/5/2018 (Agro-Meteorology Division), Meteorological Complex, Agargaon, Dhaka-1207.

Bray GN and Kurtz LT (1945), Determination of total, organic and available forms of phosphorus in soils, Soil Sci. 59: 39-45. DOI: 10.1097/00010694194501000-00006

EIU (2018), The Economist.www.eiu.com. Retrieved from https://country.eiu.com>bangladesh.

FAO (2019), Technical report - 2, Agro-ecological regions of Bangladesh for agricultural development.

Goyal S, Singh D, Suneja S and Kapoor KK (1992), Effect of rice straw compost on soil microbiological properties and yield of rice, Indian J. Agric. Res. 34(4): 263-268.

Idso SB (1991), Viewpoint: CO2 a blessing in disguise, Royal Meteorological Soci. 46(7): 207-209. DOI: 10.1002/ j.1477-86961991.tb05751.x

IPCC (2018), Technical summary In: climate change: the physical science basis. Contribution of Working Group 1 to the Forth Assessment report of the intergovernmental panel on climate change, Cambridge University Press, Cambridge, pp 996-1007.

Islam MS, Khan MHR and Hossain MS (2020), Effects of different levels of soil moisture and indigenous organic amendments on the yield of boro rice grown under field condition, Dhaka Uni. J. Biol. Sci. 29(1): 87-96.

Jackson ML (1973), Soil chemical analysis, Prentice Hall of India Pvt. Ltd., New Delhi, pp 46-183. DOI: org/10.1002/jpln.19590850311 
Krishnan P, Ramakrishnan B, Reddy KR and Reddy VR (2011), High-temperature effects on rice growth, yield and grain quality, Advances in Agron. 111: 88-205. DOI: 10.1016/B978-0-12-387689-8.00004-7

Murata Y (1976), Productivity of rice in different climatic regions of Japan. "Climate and Rice", International Rice Research Institute, Los Banos, Philippines, pp 449-470.

Nelson DW and Sommers LE (1982), Total carbon, organic carbon and organic matter In: Methods of Soil Analysis, Part 2, Ed. Page AL, Am. Soc. Agron., Publ. Madison, WI, USA: Agron. Series 9, pp 539-579.

Oh-e I, Saithoh K and Kuroda T (2007), Effects of high temperature on growth, yield and dry-matter production of rice grown in the paddy field, Plant Produc. Sci. 10(4): 412-422. DOI: org/10.1626/pps. 10.412

Page AL, Miller RH and Keeney DR (1989), Methods of soil analysis. Part-2, $2^{\text {nd }}$ Ed. American Society of Agronomy. Inc. Pub. Madison, Wisconsin, U.S.A. DOI: org/10.1002/jpln.19851480319

Piper CS (1966), Soil and plant analysis, Hano publ. Bombay, India, pp 345-368.
Richards LA (ed) (1954), Diagnosis and improvement of saline and alkali soils In: USDA handbook No.60, US Govt. Print. Office, Washington, USA, pp 84-156.

Sharma JR, Gupta RB and Panwar RD (2004), Growth, flowering and corm production gladiolus cv. Friendship as influenced by foliar application of nutrients and growth regulators, J. Ornament. Hort. 7(3): 154-158.

Stevenson FJ (1982), Humus chemistry: genesis, composition, reactions. $2^{\text {nd }}$ Ed., John Wiley \& Sons, New York, pp 343-388.

Tian X-h, Matsui T, Li SH and Lin JC (2007), High temperature stress on rice anthesis: Research progress and prospects, Chin. J. Appl. Ecol. 18: 2632-2636.

Xie XJ, Li BB, Li YX and Shen SH (2009), High temperature harm at flowering in Yangtze River basin in recent 55 years, Jiangsu J. Agric. Sci. 25: 28-32.

Yoshida S (1973), Effects of temperature on growth of rice plant (Oryza sativa L) in a controlled environment, Soil Sci. Plant Nutri. 19: 299-310. 